Biol. Stud. 2020: 14(2); 69-78 • DOI: https://doi.org/10.30970/sbi.1402.615

www.http://publications.Inu.edu.ua/journals/index.php/biology

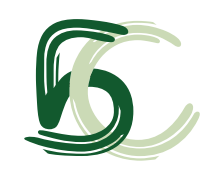

UDC: $504.53: 592](477.8)$

\title{
MODERN STATUS OF DIVERSITY OF SOIL MESOFAUNA COMMUNITIES IN MEADOW-STEPPE AREAS OF NORTHERN PODILLIA
}

\begin{abstract}
I. Y. Tsaryk ${ }^{\circledR}$, V. I. Yavornytskyi
Institute of Ecology of the Carpathians, NAS of Ukraine, 4, Kozelnytska St., Lviv 79026, Ukraine

*Corresponding author: e-mail: itsaryk@yahoo.com

Tsaryk I.Y., Yavornytskyi V.I. Modern status of diversity of soil mesofauna communities in meadowsteppe areas of Northern Podillia. Studia Biologica, 2020: 14(2); 69-78 • DOI: https://doi. org/10.30970/sbi.1402.615
\end{abstract}

Meadow-steppe vegetation was much more abundant in the past and covered large areas. However, nowadays, only small refugia of such vegetation remain due to the intensification of agriculture and significant anthropogenic transformations. These refugia, found on the slopes of hills and gullies, are of high scientific value with regard to the conservation of soil invertebrates' microhabitats. This study is the first one conducted with the purpose to investigate invertebrate mesofauna diversity in meadowsteppe areas of Northern Podillia. Soil invertebrates that belong to 40 families from six classes of three phyla are the object of our research. They are an essential component of terrestrial ecosystems due to their regulative role in the topsoil. Soil invertebrates are functionally divided into different groups, but our special attention was given to "ecosystem engineers", 13 species of Formicidae in particular, which are the organisms that significantly influence the soil by their activity. In addition, ants selectively affect the distribution of both autotrophs and heterotrophs. Formicidae alter or create micro-habitats and regulate the ability of other species to use the resources. The study presents structural and functional organization of soil invertebrate communities as well as indicators of their taxonomic diversity and dynamic density. The material was collected during 2018 field season in two relic meadow-steppe areas of the Holohoro-Voroniatsky hills of Podillia (Makitra and Bila Mts.) and analyzed according to the standard methods. In the structural and functional organization of invertebrate communities (trophic groups), phytophages prevail by their diversity (39 taxa), and zoophages predominate by dynamic density (up to $70 \%$ of numbers of collected material). Formicidae are the eudominant part among the latter. High taxonomic diversity (93 invertebrate taxa: 62 species, 11 genera, and 20 families) as well as dynamic density and dominance structure of

(C) 2020 I. Y. Tsaryk et al.; Published by the Ivan Franko National University of Lviv on behalf of Біологічні Студії / Studia Biologica. This is an Open Access article distributed under the terms of the Creative Commons Attribution License (http://www.budapestopenaccessinitiative.org and Creative Commons Attribution 4.0 License), which permits unrestricted reuse, distribution, and reproduction in any medium, provided the original work is properly cited.

ISSN 1996-4536 (print) • ISSN 2311-0783 (on-line) • Біологічні Студії / Studia Biologica • 2020 • Том 14/№2 • С. 69-78 
ground litter fauna communities in meadow-steppe areas of Northern Podillia indicate their significant role in the functioning of particular ecosystems (e.g., such steppe species as Blaps halophila Fischer von Waldheim, 1822, Myrmica deplanata Emery, 1921, Tapinoma erraticum (Latreille, 1798, etc.).

Keywords: meadow-steppe vegetation, mesofauna, soil invertebrates, "ecosystem engineers", biodiversity, Northern Podillia

\section{INTRODUCTION}

The life cycle of soil invertebrates lasts for a long time in soil [9]. Almost all groups of invertebrates are associated with soil and are an important component of terrestrial ecosystems after autotrophic organisms. Soil invertebrates perform a variety of functions in ecosystems, in particular, they decompose dead plant remains, participate in the biotic cycle, assist in the formation of primary production and soil cover, regulate microclimate and water balance, serve as food for other organisms. [5, 26, 28]. At the same time, the diversity of soil invertebrates depends on the terrain, vegetation, seasonal hydrothermal conditions etc., and is variable. Depending on the influence of various ecological factors, some changes in the ratio of the prevalent and scanty species, groups of phytophages, zoophages, saprophages and polyphages take place. The intensity of these changes significantly depends on the biotope, its present and past states. The diversity of soil invertebrates is determined by the physical and chemical structure of soil, its aeration, temperature, as well as the presence of organic matter $[1,21]$. Soil is one of the most inhabited by species ecosystem components. In this study, we focus on the research of mesofauna communities of soil and ground litter of two meadow-steppe areas of Northern Podillia, where such investigations haven't been conducted before.

Soil invertebrates are usually divided into a number of functional groups; their disappearance can lead to irreversible consequences for the ecosystem [1]. According to the Lavelle classification [12], there are key groups of soil organisms, in particular "ecosystem engineers", which are the organisms that significantly influence the soil by mixing it, constructing aggregate structures, building underground passages, and are involved in the biotic matter circulation. Besides, there is one more group of "engineers" - chemical engineers and biological regulators. The former are presented mostly by microorganisms, bacteria, and fungi. The latter are mainly protozoans, nematodes, and microartropods that control the population density in food chains, as well as the availability of resources, which are under control of chemical engineers [1]. So, "ecosystem engineers" are the organisms that alter the environmental conditions of other organisms mechanically $[11,13]$. This group includes earthworms, termites, ants, isopods and rhizosphere. One of the aspects of our work is to emphasize the role of Formicidae in the structure of soil invertebrate complex on the sample sites, and to note that soil structures of Formicidae (ant-hills) may exist even after ants have left the area. The biomass of ants, in particular biotopes, can reach 15-25\% of the biomass of all organisms. Most of the ants are non-specialized zoophages and necrophages; some of them can grow fungi and other insects in their nests [27].

The aim of our research is to determine the current status of soil mesofauna diversity, structural and functional organization of their communities with reference to the taxonomic diversity and dynamic density of meadow-steppe areas of Northern Podillia,

ISSN 1996-4536 (print) • ISSN 2311-0783 (on-line) • Біологічні Студії / Studia Biologica • 2020 • Том 14/№2 • C. 69-78 
and to characterize the species diversity of ants as "ecosystem engineers". Such a comprehensive study in this area has been undertaken for the first time.

\section{MATERIALS AND METHODS}

The study was conducted in 2018 on two relic meadow-steppe sample sites of the Holohoro-Voroniatsky hills of Podillia. They are exposed to partial artificial afforestation associated with spontaneous sylvatization involving Pinus sylvestris and some shrubs, mainly Crataegus sp., Prunus spinosa, Rosa sp., Viburnum opulus, Sambucus nigra, Corylus avellana, etc.

Sample site 1. A meadow-steppe area located on the western gully slope under the summit of Makitra Mt. (15-20 $0^{\circ}$ steepness). The xeromesophilic meadow steppes communities of Cirsio-Brachypodion pinnati union with the fragments of Festuco-Stipion (Festuco-Brometea class) and forest-steppe plots of Geranion sanguinei union (TrifolioGeranietea class) are present on sod-calcareous soils of the site [16]. Carex humilis, Festuca rupicola agg., Briza media, Elytrigia intermedia, rarely Brachypodium pinnatum and Stipa pennata dominate in the grass cover. According to the geobotanical zoning, this sample site belongs to Kremenets district of oak-hornbeam and oak-pine forests of Kremenets-Khotyn region of the East European province [2].

Sample site 2. A meadow-steppe area located on the second natural terrace of the western slope of Bila (Pidlyska) Mt. The xeromesophilic meadow steppes communities of Cirsio-Brachypodion pinnati union with the fragments of forest-steppe plots of Geranion sanguinei union (Trifolio-Geranietea class) are present on sod-calcareous soils. Carex humilis dominates in the grass cover, but, unlike the first sample site, Stipa pinnata is absent and such West Podillia endemics as Carlina onopordifolia and Chamaecytisus blockianus are present here. According to the geobotanical zoning, this sample site belongs to Holohoro-Voroniatsky district of beech forests of Kremenets-Khotyn region of the East European province [2].

The sampling and inventory of soil mesofauna was accomplished by means of Barber pitfall traps (standard glass containers ( 0.5 jars) dug into the soil at the surface level and filled up with $4 \%$ formaldehyde solution on one third). 10 traps were positioned along the line every $10 \mathrm{~m}$. The material was collected monthly from May to September.

Material analysis was carried out by standard methods [7, 8, 10]. The taxonomic composition of invertebrate communities was determined to species or higher systematic level (genus, family). Invertebrate species determination and analysis of their spatial distribution were based on a number of studies [3, 4, 6, 14, 15, 18, 19, 22, 24]. The ordering of animals into trophic groups was carried out according to B.R. Stryganova [23]. The dominance structure of invertebrate taxa was established after Tischler [25].

\section{RESULTS AND DISCUSSION}

A rich taxonomic diversity of the invertebrate soil communities in relic meadowsteppe areas of Northern Podillia - 93 taxa was revealed. These are the representatives of over 40 families from 6 classes of 3 phyla: ANNELIDA - Oligochaeta (Lumbricidae); ARTHROPODA - Malacostraca (Isopoda), Chilopoda (Geophilomorpha, Lithobiomorpha), Diplopoda (Glomeridae, Julidae), Insecta (Blattodae: Blattidae; Orthoptera: Tettigoniidae, Gryllidae, Acrididae; Dermaptera; Homoptera: Cicadidea; Hemiptera: Pyrrhocoridae, Myodochidae, Thyreocoridae; Coleoptera: Staphylinidae, Silphidae, Cantharididae, Elateridae, Alleculidae. Tenebrionidae, Cerambycidae, Chrhysomelidae,

ISSN 1996-4536 (print) • ISSN 2311-0783 (on-line) • Біологічні Студії / Studia Biologica • 2020 • Том 14/№2 • C. 69-78 
Curculionidae, Scarabaeidae; Mecoptera: Panorpidae; Diptera: Sciaridae, Bibionidae; Hymenoptera: Tenthredinidae, Formicidae; Trichoptera; Lepidoptera: Geometridae, Noctuidae); MOLLUSCA - Gastropoda (Cochlicopidae, Valloniidae, Vertiginidae, Chondrinidae, Buliminidae, Arionidae, Zonitidae, Hygromiidae, Helicidae).

The indicators of taxonomic diversity (S), dynamic density ( $N$, individuals per 100 trap-days) as well as dominance structure (\%) of invertebrate soil fauna in the communities of relic meadow-steppe areas of Northern Podillia are presented in Table 1.

It was found out that mesofauna communities of the investigated sites 1 (Makitra Mt.) and 2 (Bila Mt.) being similar by taxonomic structure, differ by the dynamic density of some invertebrate groups (Table 1). Insects having the highest indicators of diversity (up to $60 \%$ ) and dynamic density (up to $80 \%$ ) dominate in the communities in general. Among the other taxa Oniscoidea and Diplopoda show high diversity too, being dominants and subdominants by dominance structure, while the rest of the taxa are recedents and subrecedents (Table 1).

In the structural and functional organization of the invertebrate communities (trophic groups), phytophages prevail by their diversity (39 taxa), and zoophages predominate by the dynamic density (up to $70 \%$ of numbers in collected material) (Table 2).

Formicidae, being a part of the zoophagous trophic group, dominate by dynamic density within the group in both areas: Makitra Mt. $-69 \%$ and Bila Mt. $-86 \%$. The parts of other zoophages are considerably lower.

Formicidae species found on the sample sites are as follows: Formica cunicularia Latreille, 1798, F. rufibarbis Fabricius, 1793, Lasius paralienus Seifert, 1992, L. niger (Linnaeus, 1758), L. flavus (Fabricius, 1782), Tetramorium caespitum (Linnaeus, 1758), T. impurum (Foerster, 1850), M. scabrinodis Nylander, 1846, Temnothorax crassispinus (Karawajew, 1926), Leptothorax acervorum (Fabricius, 1793), Lasius plathythorax Seifert, 1991. We also detected Myrmica deplanata Emery, 1921, which is a steppe termophilic species typical of open biotopes with sparse grass vegetation (site 1), and Tapinoma erraticum (Latreille, 1798) that inhabits dry warm areas (site 1). Actually, the two latter species are the indicators of steppe areas [19].

Formicidae, being "ecosystem engineers" who alter the environment for other invertebrate groups of ground litter mesofauna by their activity, are eudominants (60$70 \%$ ) among the insects by the indicator of dynamic density.

Tenebrionidae (imago and larvae) - 28-44 \%, Curculionidae - 14-21\%, Hemiptera (Pyrrhocoridae, Myodochidae, Thyreocoridae) - 12-18 \%, Orthoptera (Tettigoniidae, Gryllidae, Acrididae) - 4-17\% dominate within the phytophages by dynamic density. Oniscoidea - 27-29 \%, Diplopoda - 9-56 \% (high value for site 2), and Blattodea (Ectobius sylvestris (Poda, 1761) - up to $50 \%$ at site 1 prevail among saprophages. Dermaptera (Forficula auricularia Linnaeus, 1758), Silphidae (Necrophorus vespillo Linnaeus, 1758), and Diptera larvae (Sciaridae, Bibionidae), Gastropoda have a considerable representation as well.

Lumbricidae in our material are presented at the level of recedents and their part in total dynamic density does not exceed $1 \%(0.1-0.6 \%)$, which accounts for their coincidental representation in the traps.

Diplopoda are represented by 6 species from 2 families: Glomeridae (Glomeris hexasticha Brandt, 1833), Julidae (Cylindroiulus burzenlandicus Verhoeff, 1907, Enantiulus nanus (Latzel, 1884), Megaphyllum sjaelandicus (Meinert, 1868), Ommatoiulus sabulosus (Linnaeus, 1758), Unciger foetidus (C.L.Koch, 1847)). These are pan-European,

ISSN 1996-4536 (print) • ISSN 2311-0783 (on-line) • Біологічні Студії / Studia Biologica • 2020 • Том 14/№2 • C. 69-78 
Table 1. Indicators of taxonomic diversity (S) and dynamic density (N (\%), individuals per 100 trap-days) of invertebrate mesofauna of meadow-steppe areas of Northern Podillia

Таблиця 1. Показники різноманіття таксонів (S) і динамічної щільності (N (\%), особин на 100 пасткодіб) безхребетних мезофауни лучно-степових ділянок Північного Поділля

\begin{tabular}{|c|c|c|c|c|c|c|c|}
\hline \multirow{2}{*}{ Taxon } & \multirow{2}{*}{$S$} & \multicolumn{3}{|c|}{ Makitra Mt., 2018} & \multicolumn{3}{|c|}{ Bila Mt., 2018} \\
\hline & & $S$ & $N$ & $\%$ & $S$ & $\mathrm{~N}$ & $\%$ \\
\hline Lumbricidae & 1 & 1 & 1 & 0.08 & 1 & 0.5 & 0.04 \\
\hline Oniscoidea & 1 & 1 & 77 & 6.54 & 1 & 142 & 11.23 \\
\hline Aranei & 1 & 1 & 102 & 8.67 & 1 & 22.7 & 1.80 \\
\hline Opiliones & 1 & 1 & 1 & 0.08 & 1 & 3.7 & 0.29 \\
\hline Chilopoda & 2 & 2 & 6.4 & 0.54 & 2 & 3.9 & 0.31 \\
\hline Diplopoda & 6 & 5 & 25.3 & 2.15 & 3 & 273 & 21.59 \\
\hline Blattidae & 2 & 2 & 150 & 12.75 & 2 & 13.4 & 1.06 \\
\hline Orthoptera & 3 & 2 & 2.9 & 0.25 & 3 & 21.7 & 1.72 \\
\hline Dermaptera & 2 & 2 & 2.1 & 0.18 & 1 & 39.6 & 3.13 \\
\hline Cicadidea & 1 & 1 & 3.6 & 0.31 & 1 & 4.1 & 0.32 \\
\hline Hemiptera & 5 & 4 & 9.3 & 0,79 & 4 & 17.3 & 1.37 \\
\hline Carabidae & 1 & 6 & 62.8 & 5.34 & 5 & 7.7 & 0.61 \\
\hline Staphylinidae & 5 & 4 & 50 & 4.25 & 5 & 32.8 & 2.59 \\
\hline Silphidae & 1 & 1 & 0.3 & 0.03 & 1 & 17.6 & 1.39 \\
\hline Cantharididae (lar., im.) & 2 & 2 & 0.8 & 0.07 & 2 & 1.6 & 0.13 \\
\hline Adephaga (lar.) & 1 & 1 & 1.7 & 0.14 & 1 & 3.4 & 0.27 \\
\hline Elateridae (im.) & 7 & 5 & 2.4 & 0.20 & 3 & 1.3 & 0.10 \\
\hline Alleculidae (im.) & 1 & 1 & 1.5 & 0.13 & - & - & - \\
\hline Tenebrionidae (lar., im.) & 5 & 5 & 33.5 & 2.85 & 5 & 27 & 2.14 \\
\hline Cerambycidae & 1 & 1 & 0.1 & 0.01 & 1 & 0.5 & 0.04 \\
\hline Chrysomelidae (im.) & 2 & 1 & 2.6 & 0.22 & 1 & 1.6 & 0.13 \\
\hline Curculionidae (im.) & 9 & 8 & 15.8 & 1.34 & 4 & 13.6 & 1.08 \\
\hline Scarabaeidae (im.) & 4 & 3 & 3.1 & 0.26 & 4 & 7.7 & 0.61 \\
\hline Coleoptera sp. & 1 & 1 & 0.1 & 0.01 & - & - & - \\
\hline Mecoptera, Panorpidae (lar.) & 1 & 1 & 0.1 & 0.01 & - & - & - \\
\hline Diptera: Sciaridae (lar.) & 1 & 2 & 17.5 & 1.49 & 2 & 0.5 & 0.04 \\
\hline Diptera: Bibionidae (lar.) & 1 & 1 & 4.1 & 0.35 & - & - & - \\
\hline Tenthredinidae (lar.) & 1 & 1 & 0.1 & 0.01 & 1 & 1.5 & 0.12 \\
\hline Formicidae (im.) & 4 & 3 & 562 & 47.76 & 3 & 582 & 46.03 \\
\hline Trichoptera (lar.) & 3 & 3 & 30.3 & 2.57 & 2 & 16.8 & 1.33 \\
\hline Insecta sp. (im.) & 1 & 1 & 0.1 & 0.01 & - & - & - \\
\hline Lepidoptera (lar.) & 2 & 1 & 1 & 0.08 & 2 & 1.7 & 0.13 \\
\hline Mollusca & 14 & 11 & 6.2 & 0.53 & 5 & 5 & 0.40 \\
\hline Total & 93 & 85 & 1177 & 100 & 66 & 1264 & 100 \\
\hline Saprophages & 29 & 28 & 283 & 24 & 17 & 492 & 39 \\
\hline Phytophages & 39 & 33 & 76 & 6.5 & 28 & 97 & 7.6 \\
\hline Zoophages & 25 & 24 & 818 & 69.5 & 21 & 675 & 53.4 \\
\hline
\end{tabular}


Table 2. Trophic groups of invertebrate mesofauna of meadow-steppe areas of Northern Podillia (S - taxonomic diversity, N (\%) - dynamic density)

Таблиця 2. Трофічні групи мезофауни безхребетних лучно-степових ділянок Північного Поділля (S - різноманіття таксонів, N (\%) - динамічна щільність)

\begin{tabular}{|c|c|c|c|c|c|c|c|}
\hline \multirow{2}{*}{ Taxon } & \multirow{2}{*}{ S } & \multicolumn{3}{|c|}{ Makitra Mt., 2018} & \multicolumn{3}{|c|}{ Bila Mt., 2018} \\
\hline & & $S$ & $\mathrm{~N}$ & $\%$ & S & $\mathrm{N}$ & $\%$ \\
\hline Saprophages & 29 & 28 & 283 & 100 & 17 & 492 & 100 \\
\hline Lumbricidae & 1 & 1 & 1 & 0.35 & 1 & 0.5 & 0.10 \\
\hline Oniscoidea & 1 & 1 & 77 & 27.18 & 1 & 142 & 28.86 \\
\hline Mollusca & 12 & 11 & 6.2 & 2.19 & 5 & 5 & 1.02 \\
\hline Diplopoda & 6 & 5 & 25.3 & 8.94 & 4 & 273.4 & 55.57 \\
\hline Blattodea (Ectobius sylvestris) & 2 & 2 & 149.5 & 52.78 & 2 & 13,4 & 2.72 \\
\hline Dermaptera (Forficula auricularia) & 2 & 2 & 2.1 & 0.74 & 1 & 39.6 & 8.05 \\
\hline Silphidae (Necrophorus vespillo) & 1 & 1 & 0.3 & 0.11 & 1 & 17.6 & 3.58 \\
\hline Insecta sp. (im.) & 1 & 1 & 0.1 & 0.04 & - & - & - \\
\hline Diptera: Sciaridae (lar.) & 1 & 2 & 17.5 & 6.18 & 2 & 0.5 & 0.10 \\
\hline Diptera: Bibionidae (lar.) (Bibio marci) & 1 & 1 & 4.1 & 1.45 & - & - & - \\
\hline Coleoptera sp. & 1 & 1 & 0.1 & 0.04 & - & - & - \\
\hline Phytophages & 39 & 33 & 76 & 100 & 28 & 97 & 100 \\
\hline Tettigonidae & 3 & 2 & 2.9 & 3.83 & 2 & 16.1 & 16.68 \\
\hline Gryllidae & 1 & - & - & - & 1 & 5.6 & 5.77 \\
\hline Cicadodea & 1 & 1 & 3.6 & 4.76 & 1 & 4.1 & 4.23 \\
\hline Hemiptera & 5 & 5 & 9.3 & 12.28 & 4 & 17.3 & 17.94 \\
\hline Elateridae (im.) & 6 & 5 & 2.4 & 3.17 & 3 & 1.3 & 1.34 \\
\hline Alleculidae (Lagria hirta) (im.) & 1 & 1 & 1.5 & 1.98 & - & - & - \\
\hline Tenebrionidae (im.) & 5 & 5 & 33.5 & 44.17 & 5 & 27 & 28.06 \\
\hline Cerambycidae (Dorcadion holosericeum) & 1 & 1 & 0.1 & 0.13 & 1 & 0.5 & 0.52 \\
\hline Chrhysomelidae (im.) & 1 & 1 & 2.6 & 3.43 & 1 & 1.6 & 1.65 \\
\hline Lepidoptera (lar.) & 2 & 1 & 1 & 1.32 & 2 & 1.7 & 1.75 \\
\hline Curculionidae (im.) & 9 & 8 & 15.8 & 20.83 & 4 & 13.6 & 14.12 \\
\hline Scarabaeidae (im.) & 4 & 3 & 3.1 & 4.10 & 4 & 7.7 & 7.94 \\
\hline Zoophages & 25 & 24 & 818 & 100 & 21 & 675 & 100 \\
\hline Aranei & 1 & 1 & 102 & 12.49 & 1 & 22.7 & 3.36 \\
\hline Opiliones & 1 & 1 & 1 & 0.12 & 1 & 3.7 & 0.55 \\
\hline Chilopoda & 2 & 2 & 6.4 & 0.78 & 2 & 3.9 & 0.58 \\
\hline Carabidae & 6 & 6 & 62.8 & 7.69 & 5 & 7.7 & 1.14 \\
\hline Staphylinidae & 5 & 4 & 50 & 6.11 & 4 & 32.8 & 4.86 \\
\hline Cantharididae (Cantharis rustica) (lar., im.) & 2 & 2 & 0.8 & 0.10 & 2 & 1.6 & 0.24 \\
\hline Adephaga (lar.) & 1 & 1 & 1.7 & 0.21 & 1 & 3.4 & 0.50 \\
\hline Formicidae (im.) & 3 & 3 & 562.4 & 68.78 & 2 & 580.9 & 86.06 \\
\hline Trichoptera (lar.) & 2 & 2 & 30.3 & 3.70 & 2 & 16.8 & 2.49 \\
\hline Mecoptera, Panorpidae (lar.) (P. communis) & 1 & 1 & 0.1 & 0.01 & - & - & - \\
\hline Tenthredinidae (lar.) & 1 & 1 & 0.1 & 0.01 & 1 & 1.5 & 0.22 \\
\hline Total & 93 & 85 & 1177 & 100 & 66 & 1264 & 100 \\
\hline
\end{tabular}

ISSN 1996-4536 (print) • ISSN 2311-0783 (on-line) • Біологічні Студії / Studia Biologica • 2020 • Том 14/№2 • C. 69-78 
forest-steppe species also typical of broadleaf oak-hornbeam and pine forests on sandy soils; they are common meso-calciphils [17]. The dynamic density of Diplopoda is considerable and varies from 25 to 273 individuals per 100 trap-days (Table 2). The dominance structure of other taxa reveals recedent and subrecedent levels (Tables 1 and 2).

Blattodea, Ectobius sylvestris (Poda, 1761) in particular (max. 150 individuals per 100 trap-days), and Dermaptera (Forficula auricularia Linnaeus, 1758) (up to 40 individuals per 100 trap-days) are the most common representatives of saprophages. The rest of insects are presented mostly by imago and larvae of Silphidae (Necrophorus vespillo Linnaeus, 1758), while larvae of Diptera (Sciaridae, Tipulidae, Bibionidae (Bibio marci Linnnaeus (1758)) are sparse.

Imago and larvae of Tenebrionidae (Pedinus femoralis L., 1767, Opatrum sabulosum L., 1761, Blaps halophila is less likely) have a considerable representation within the investigated communities. These bugs are typical steppe and desert inhabitants and phytopages by their trophic specialization. The presence of these species on the research sites testifies the value of their habitats within the refugia of meadow steppe vegetation of Northern Podillia.

7 Elateridae species were found in the invertebrate communities. Adrastus pallens (Fabricius, 1792), Lacon murinus (Linnaeus, 1758) and Melanotus rufipes (Herbst, 1784), being forest-steppe and meadow mesofiles, dominate by the indicator of dynamic density. Agriotes gallidus Boisduval \& Lacordaire, 1835, Serica brunnea (Linnaeus, 1758), Athous haemorrhoidalis Fabricius, 1801 and Actenicerus sjelandicus (O.F. Mueller, 1764), being forest species, appear quite often as well.

Scarabaeidae are presented by such phytophages as Cetonia aurata (Linnaeus, 1758) and Epicometis hirta (Poda, 1761), and such coprophages as Aphodius fossor (Linnaeus, 1758) and Gymnopleurus sp.

9 species of Curculionidae were found in the material. The most common genus within the family is Otiorhynchus (O. scaber (Linnaeus, 1758), O. sulcatus Fabricius, 1775 , O. niger Fabricius, 1775, etc.), while others appeared less frequently (Barypeithes araneiformis (Schrank, 1781). Phyllobius pyri (Linnaeus, 1758), Tanymecus palliates (Fabricius, 1787), Zacladus affinis (Paykull, 1792), Liparus glabrirostris Kuster, 1849).

We also identified 14 species of mollusks from 9 families. They are as follows: Cochlicopidae (Cochlicopa lubricella (Rossmassler, 1835), Valloniidae (Vallonia pulchella (O.F. Muller, 1774)), Vertiginidae (Truncatellina cylindrica (A. Ferussac, 1807)), Chondrinidae (Granaria frumentum (Draparnaud, 1801)), Chondrina clienta (Westerlund, 1883)), Buliminidae (Chondrula tridens (Muller, 1774)), Arionidae (Arion subfuscus (O.F. Muller, 1774)), Zonitidae (Nesovitrea hammonis (Stom, 1765)), Oxychilus sp.), Hygromiidae (Helicopsis striata (O.F. Muller, 1774)), H. instabilis (Rossmassler, 1838), Helicella candicans (L.Pfeiffer, 1841), Euomphalia strigella (Draparnaud, 1801), Helicidae (Cepaea vindobonensis (Ferussac, 1821)). These species are common for the lowland part of Western Ukraine, $70 \%$ of them being steppe calciphils. Their typical habitats are open dry biotopes, warm slopes with low grass vegetation, and denudations of geological strata [24]. The rare species included in the Red Data Book of Ukraine is Granaria frumentum (Draparnaud, 1801) [20]. The dynamic density of terrestrial mollusks is low and doesn't exceed 5-6 individuals per 100 trap-days.

We suggest protecting the unique meadow-steppe areas of Northern Podillia from the consequences of the transformation processes caused by sylvatization as it might change soil mesofauna. The species whose distribution is not typical of this territory will be affected in the first place. 


\section{CONCLUSIONS}

The invertebrate communities in the relic meadow-steppe areas under study are distinguished by significant taxonomic diversity (93 invertebrate taxa: 62 species, 11 genera, and 20 families) and high indicators of dynamic diversity (Formicidae - up to 581 individuals per 100 trap-days, Diplopoda - up to 273 individuals per 100 trap-days). The presence of typically steppe species such as Blaps halophila, Myrmica deplanata, Tapinoma erraticum on the sites confirms the idea of great value and uniqueness of these relic areas among the lands transformed by anthropogenic influence. Besides, the invertebrate species that represent different trophic groups play a significant role as indicators of refugia of meadow-steppe vegetation on the territory of Northern Podillia (zoophages - 53.4-69.5\%, saprophages - 24-39\%, phytophages - 6.5-7.6 \%).

The study has revealed that soil invertebrate communities of the investigated areas (Makitra and Bila Mts.) are similar to each other by the quantitative indicators of dynamic density and functional organization.

13 species of Formicidae that were found on the sites are "ecosystem engineers" by their functional role. One of the most important ecological tasks nowadays is to ascertain the functional role of every animal taxon (at least the dominant one) in maintaining the long-term sustainable existence of ecosystems.

We would like to express our appreciation to Prof. O. Radchenko and our collegues from Ecosystemology Department of Institute of Ecology of the Carpathians of National Academy of Sciences of Ukraine for their help and advice.

\section{COMPLIANCE WITH ETHICAL STANDARDS}

Conflict of Interest: The authors declare that the research was conducted in the absence of any commercial or financial relationships that could be construed as a potential conflict of interest.

Animal Rights: This article does not contain any results of studies with animal subjects performed by the any of the authors.

1. Assessment of soil biodiversity policy instruments in EU-27, Draft final report. 2009. European Commission DG ENV. Bio Intelligence Service. 232 p.

2. Barbarych A.I. (Ed.) Geo-botanical zoning of the Ukrainian SSR. Kyiv: Naukova Dumka, 1977. 303 p. (In Ukrainian)

3. Birkhofer K., Gossner M., Diekötter T., Drees C., Ferlian O., Maraun M., Scheu S., Weisser W., Wolters V., Wurst S., Zaitsev A., Smith H. Land-use type and intensity differentially filter traits in above- and below-ground arthropod communities. J. Anim. Ecol., 2017; 86(3): 511-520. [DOI: https://doi.org/10.1111/1365-2656.12641; PMid: 28118484; Google Scholar]

4. Burakowski B., Mroczkowski M., Stefańska J. Coleoptera: Carabidae, Catalogue of Polish fauna, Vol. 23, Iss. 2. Warsaw: State Scientific Publishing House, 1974. 430 p.

5. Cameron E.K., Martins S., Lavelle P., Mathieu J., Tedersoo L., Gottschall F., Guerra C.A., Hines J., Patoine G., Siebert J., Winter M., Cesarz S., Delgado-Baquerizo M., Ferlian O., Fierer N., Kreft H., Lovejoy T.E., Montanarella L., Orgiazzi A., Pereira H.M., Phillips H.R.P., Settele J., Wall D.H., Eisenhauer N. Global gaps in soil biodiversity data. Nat. Ecol. Evol., 2018; 2(7): 1042-1043.

[DOI: https://doi.org/10.1038/s41559-018-0573-8; PMid: 29867100; Google Scholar]

6. Dolin V.G. Coleoptera: Elateridae: Cardiophorinae and Elaterinae, Fauna of Ukraine, Vol.19, Iss. 4. Kyiv: Naukova Dumka, 1988. 204 p. (In Russian)

ISSN 1996-4536 (print) • ISSN 2311-0783 (on-line) • Біологічні Студії / Studia Biologica • 2020 • Том 14/№2 • C. 69-78 
7. Dunger W., Fiedler H.J. Soil Biology Methods. Stuttgart;New York: Gustav Fischer Publishing, 1989. $432 \mathrm{p}$.

8. Dylis N.V. Program and methods of biogeocoenological investigations. Moscow: Nauka, 1974. 404 p. (In Russian)

9. Eijsackers $H$. Ecotoxicology of soil organisms: seeking the way in a pitch dark labyrinth. In: Donker M.H., Eijsackers H., Heimbach F. (Eds.) Ecotoxicology of soil organisms. London; Tokyo: Lewis Publ., 1994: P. 3-32.

10. Gilarov M.S. (Ed.) Methods of soil-zoological research. Moscow: Nauka, 1975. 280 p. (In Russian)

11. Jones C.V., Lawton J.H., Shachak M. Positive and negative effects of organisms as physical ecosystem engineers. Ecology, 1997; 78: 1946-1957.

[DOI: https://doi.org/10.1890/0012-9658(1997)078[1946:PANEOO]2.0.CO;2; Google Scholar]

12. Lavelle P., Bignell D., Lepage M., Wolters V., Roger P.-A., Ineson P., Heal O.W., Dhillion S. Soil function in a changing world: the role of invertebrate ecosystem engineers. Eur. J. Soil Biol., 1997; 33(4): 159-193.

13. Lavelle P., Spain A.V. Soil ecology. Amsterdam: Kluwer Academic Publishers, 2005. 662 p.

14. Lokshina I.E. Key for the identification of Diplopoda of lowland part of European part of the USSR. Moscow: Nauka, 1969. 78 p. (In Russian)

15. Mamaev B.M. Key for the identification of insect larvae. Moscow: Prosveshchenie, 1972. 410 p. (In Russian)

16. Matuszkiewicz W. Key for the identification of plant communities of Poland. Warsaw: State Scientific Publishing House, 2002. 540 p.

17. Negrobov O.P., Negrobova E.A. Ecological and faunistic characteristics of millipedes (Myriapoda, Diplopoda) of Mid-Russian forest-steppe, Student book. Voronezh: Voronezh State University Press, 2007. 39 p. (In Russian)

18. Plavilshchikov N.N. Key for the identification of insects: Brief key to the most common insects of the European part of Russia. Moscow: Topikal, 1994. 544 p. (In Russian).

19. Radchenko O.H. Ants (Hymenoptera, Formicidae) of Ukraine. Kyiv, 2016. 480 p. (In Ukrainian)

20. Red Data Book of Ukraine. Animals. Kyiv: GlobalConsulting, 2009. 600 p. (In Ukrainian)

21. Risch A.C., Ochoa-Hueso R., van der Putten W.H., Bump J.K., Busse M.D., Frey B., Gwiazdowicz D.J., Page-Dumroese D.S., Vandegehuchte M.L., Zimmermann S., Schütz M. Sizedependent loss of aboveground animals differentially affects grassland ecosystem coupling and functions. Nat. Commun., 2018; 9: 3684.

[DOI: https://doi.org/10.1038/s41467-018-06105-4; PMid: 30206214; Google Scholar]

22. Rizun V.B. Carabidae of the Ukrainian Carpathians. Lviv, 2003. 210 p. (In Ukrainian)

23. Striganova B.R. Feeding of soil saprophages. Moscow: Nauka, 1980. 244 p. (In Russian)

24. Sverlova N.V., Hural R.I. A key for the identification of terrestrial mollusks of Western Ukraine. Lviv, 2005. 218 p. (In Ukrainian)

25. Tischler W. Einführung in die Ökologie. 1. Stuttgart;New York, 1979. 215 p.

26. Wardle D.A., Bardgett R.D., Klironomos J.N., Setälä H., van der Putten W.H., Wall D.H. Ecological linkages between aboveground and belowground biota. Science, 2004; 304(5677): 1629-1633.

[DOI: https://doi.org/10.1126/science.1094875; PMid: 15192218; Google Scholar]

27. Wilson E.O., Holldobler $B$. The rise of the ants: a phylogenetic and ecological explanation. Proc. Nat. Acad. Sci. USA, 2005; 102: 7411-7414.

[DOI: https://doi.org/10.1073/pnas.0502264102; PMid: 15899976; Google Scholar]

28. Yavornytskyi V.I. The abundance and mass dynamics of soil mesofauna. In: Chernobai Y.M. (Ed.) Ecology and fauna of soil invertebrates of Western Volyn-Podilla. Kyiv: Naukova Dumka, 2003: 312-318. (In Russian) 


\title{
СУЧАСНИЙ СТАН РІЗНОМАНІТТЯ УГРУПОВАНЬ ҐРУНТОВОЇ МЕЗОФАУНИ ЛУЧНО-СТЕПОВИХ ДІЛЯНОК ПІВНІЧНОГО ПОДІЛЛЯ
}

\author{
І. Й. Царик*, В. І. Яворницький \\ Інститут екології Карпат НАН України, вул. Козельницька, 4, Львів 79026, Україна \\ *Кореспондуючий автор: e-mail: itsaryk@yahoo.com
}

Лучно-степова рослинність у історичному минулому займала досить значні обсяги територій, але з інтенсифікацією сільського господарства та значною антропогенною трансформацією середовища тепер залишилися тільки незначні осередки таких рефугіумів природної рослинності. Невеликі ділянки лучно-степової рослинності на схилах пагорбів та балок становлять велику наукову цінність у контексті збереження мікрооселищ ґрунтових безхребетних. Власне з цих позицій і були виконані вперше дослідження різноманіття мезофрауни безхребетних в угрупованнях, які характеризують лучно-степові ділянки Північного Поділля. Об'єктом вивчення було обрано ґрунтових безхребетних, які належали до 40 родин із шести класів трьох типів. Їхня роль у функціонуванні наземних екосистем $€$ важливою у плані регулювання ґрунтотворних процесів. Ґрунтові безхребетні за своєю фрункціональною суттю поділяються на різні групи. У цій роботі було звернуто увагу на так званих "інженерів екосистем", зокрема, Formicidae (13 видів), оскільки це організми, які суттєво впливають на ґрунт своєю активною діяльністю. Окрім цього, мурашки вибірково впливають на поширення як автотрофрів, так і гетеротрофів. Formicidae змінюють або створюють безпосередньо мікрооселища та регулюють можливість споживання ресурсів іншими видами. Структурно-фрункціональна організація угруповань ґрунтових безхребетних і показники їхнього таксономічного різноманіття і динамічної щільності висвітлені у цій роботі. Матеріал було зібрано протягом польового сезону 2018 року на двох реліктових лучно-степових ділянках Гологоро-Вороняцького горбогір'я Подільської височини (гг. Макітра і Біла). Збір та опрацювання матеріалу проводили згідно з загальноприйнятими методиками. Встановлено, що у структурно-функціональній організації угруповань безхребетних (трофрічні групи) за різноманіттям переважають фрітофраги (39 таксонів), а за показником динамічної щільності - хижаки (до 70 \% чисельності зібраного матеріалу). Серед них еудомінантом $€$ Formicidae. Таксономічне різноманіття (93 таксони безхребетних: 62 види, 11 родів, 20 родин) та показники динамічної щільності і структури домінування в угрупованнях безхребетних підстилково-ґрунтової фрауни лучно-степових ділянок Північного Поділля вказують на унікальність цих територій та їхню значну роль у функціонуванні окремих екосистем (наприклад, степові види Blaps halophila, Myrmica deplanata, Tapinoma erraticum тощо).

Ключові слова: лучно-степова рослинність, мезофауна, ґрунтові безхребетні, “інженери екосистем", біорізноманіття, Північне Поділля 